\title{
Mitomycin C Analog KW-2149
}

National Cancer Institute

\section{Source}

National Cancer Institute. Mitomycin C Analog KW-2149. NCI Thesaurus. Code C1140.

A semisynthetic water-soluble disulfide derivative of the antineoplastic antibiotic mitomycin C. Activated by serum and glutathione, KW-2149 causes interstrand DNA cross-links and DNA-protein cross-links, resulting in single-strand DNA breaks and inhibition of DNA synthesis. ( $\mathrm{NCIO4)}$ 